ISSN 1678-3921

Journal homepage: www.embrapa.br/pab

For manuscript submission and journal contents, access: www.scielo.br/pab
Danielly Daiane Felix da Silva ${ }^{(1 凶)}(3$, Fernanda Viana da Silva Leonardo(2) and Sidney Fernando Caldeira ${ }^{(2)}(3)$

(1) Universidade Federal de Mato Grosso, Campus Sinop, Instituto de Ciências Agrárias e Ambientais, Avenida Alexandre Ferronato, no 1.200, Setor Industrial, CEP 78557-267 Sinop, MT, Brazil. E-mail: daniellydfelixs@gmail.com

(2) Universidade Federal de Mato Grosso, Avenida Fernando Corrêa da Costa, o 2.367, Boa Esperança, CEP 78060-900 Cuiabá, MT, Brazil.

E-mail: viana.fernandaleonardo@gmail.com, sidneycal@gmail.com

$凶$ Corresponding author

Received

August 13, 2018

Accepted

June 25, 2019

How to cite

SILVA, D.D.F. da; LEONARDO, F.V. da S.; CALDEIRA, S.F. Vulnerability of African mahogany to cattle predation in a silvipastural system. Pesquisa Agropecuária Brasileira, v.54, e00987, 2019. DOI: https://doi. org/10.1590/S1678-3921.pab2019.v54.00987.

\section{Vulnerability of African mahogany to cattle predation in a silvipastural system}

\begin{abstract}
The objective of this work was to evaluate the incidence and intensity of damages caused by cattle to African mahogany (Khaya grandifoliola) and this species vulnerability in the silvipastural system. The trees were planted in single lines, in a 20x2 m arrangement. In the third year, cattle were introduced in the area. Three classes of damage intensity were established: low, medium, and high. Damages to tree barks showed the highest incidence, followed by damages to wood. The species is vulnerable to bark chewing by cattle, with damages of medium and high intensities.
\end{abstract}

Index terms: Khaya grandifoliola, damage by animal, crop-livestock-forest integration, forest component.

\section{Vulnerabilidade de mogno-africano à predação por bovinos em sistema silvipastoril}

Resumo - O objetivo deste trabalho foi avaliar a incidência e a intensidade de danos causados por bovinos ao mogno-africano (Khaya grandifoliola) e a vulnerabilidade desta espécie em sistema silvipastoril. As árvores foram plantadas em linhas simples, arranjadas em $20 \times 2 \mathrm{~m}$. No terceiro ano, os bovinos foram introduzidos na área. Foram estabelecidas três classes de intensidade de danos: baixa, média e alta. Os danos causados às cascas das árvores foram os de maior incidência, seguidos por danos causados ao lenho. A espécie é vulnerável à mastigação da casca por bovinos, com danos de média e alta intensidades.

Termos para indexação: Khaya grandifoliola, dano animal, integração lavoura-pecuária-floresta, componente florestal.

The silvipastural system, known as crop-livestock-forest integration system (CLFIS), is an alternative to production because it reduces the effects caused by standardized and simplified systems. It is also a dynamic and complex system, as it involves the integration of elements of different aspects (Balbino et al., 2011). It is considered a highinvestment forest component, whose results are obtained in the long term (Kichel et al., 2014); therefore, the species selection and its genetic material are important points to be considered for the success of this system.

The input of the animal component into the system may be damaging to the forest component, depending on the species that was chosen, the management applied, and the size and age of the trees. Damage to trees occurs more easily when they are young as this is a critical phase. In addition, damage impairs the development of these individuals more 
than in trees that are already established and with enough size to withstand the negative impact caused by animals (Lehmkuhler et al., 2003; Fike et al., 2004).

Studies on the prediction of such damage and mortality in relation to the establishment and initial development of the plants focused on Eucalyptus dunnii, Grevillea robusta, and Schinus terebinthifolius (Porfírio-da-Silva et al., 2012), and in E. grandis x E. camaldulensis (Brun et al., 2017).

Among the exotic species, Khaya grandifoliola C.DC., initially identified as $K$. ivorensis and known as African mahogany, it is native to the West Africa and has a consolidated commercial use. African mahogany was introduced in Brazil to replace Swietenia macrophylla due to its resistance to the Hypsipyla grandella Zeller, the main pest of Brazilian mahogany (Klein et al., 2016).

The objective of this work was to evaluate the incidence and intensity of the damage caused by animals to Khaya grandifoliola, as well as this species vulnerability in the silvipastural system.

The study was performed on a crop in an croplivestock-forest integration system (CLFIS), in the municipality of Araputanga, in the southwest of Mato Grosso state, Brazil, within $15^{\circ} 29^{\prime} 39.42^{\prime \prime S}$ and $58^{\circ} 24^{\prime} 46.18^{\prime \prime} \mathrm{W}$.

The study area was previously occupied by Urochloa brizantha 'MG-5' (Syn. Brachiaria brizantha 'MG-5') and used for cattle raising. In different paddocks, clonal saplings of $K$. grandifoliola and Tectona grandis were planted in single lines in 2010 . For the 80.23 ha total area, the spacing adopted between the plants was $2 \mathrm{~m}$ and $20 \mathrm{~m}$ between lines, which resulted in the density of 250 trees per ha.

In the first three years, the forest species were intercropped with tillage and pasture grass in the subsequent years. Cattle grazing started in 2013 for the breedings Aberdeen Angus x Nellore, Nellore x Caracu and Aberdeen Angus x Brahman animals. Grazing was done in rotation, and the animals remained for seven days in every 25 ha picket, with the occupancy of three animals per unit (AU) per hectare.

Data used in the present work are from $K$. grandifoliola trees representing $30 \%$ of the total trees planted in the area. In 2016, 8 plots of 25 trees each were systematically allocated in this portion. Failures were considered, whenever they occurred, in such a way that each failed plot contained less than 25 individuals. When trees were at six years of age, the following parameters were measured: the diameter at $1.3 \mathrm{~m}$ breast height $(\mathrm{DBH})$, total height $(\mathrm{Ht})$; and the marketable height $(\mathrm{Hc})$, from the point of insertion of the first branch that continuously composed the canopy. The heights were measured with a hypsometer EC II D (Haglöf, Sweden), and the DBH was measured with a diameter caliper.

In the same year, damages observed in $K$. grandifoliola trees caused by the insertion of the animal component into the system had their length (Dl) and width (Dw) measured with a tape measure.

Damages caused by cattle were quantitatively performed through the following equation Damage $(\%)=\left(\mathrm{D} 1 \times \mathrm{Dw} \times \mathrm{W} / \mathrm{H}_{\mathrm{c}} \times \mathrm{CBH}\right) \times 100$, in which the values were expressed in frequency (\%), by the relation between the damage proportion and the marketable trunk proportion.

In this equation, Damage (\%) is the proportion of damage to trees; Dl, is the length of damage $(\mathrm{cm})$; Dw is the damage width $(\mathrm{cm}) ; \mathrm{Hc}$ is the marketable height of the tree; $\mathrm{CBH}$, is the $1.3 \mathrm{~m}$ circumference at breast height; and $\mathrm{W}$ is the weight adopted according to the type of damage.

For the elaboration of the weight system, the method adapted from Porfírio-da-Silva et al. (2012) was used, in which the weight was established for each type of damage, as follows: 10.0, trunk breakage with imminent mortality; 4.0, deep injury with wood impairment wood; and 2.0, superficial injury with bark impairment. In addition, to determine the intensity of the damage, the following damage intensity classes were used: low $(<10 \%)$; average $(10 \%$ to $30 \%)$; and high $(>30 \%)$.

The measurements were performed for six-year-old plants, the following averages were observed: $12.7 \mathrm{~m}$ $\mathrm{Ht} ; 6.9 \mathrm{~cm} \mathrm{Hc}$; and $16.62 \mathrm{~cm} \mathrm{DBH}$. The basal area (G) was equivalent to $3.74 \mathrm{~m}^{2} \mathrm{ha}^{-1}$. Visually, the trees showed a moderate variability for DBH and total height (Table 1). The dendrometric characteristics observed in the present study corroborate those reported by Castro et al. (2008) for silvipastural systems in which African mahogany can reach $12 \mathrm{~m}$ trunk height, with $22 \mathrm{~cm}$ $\mathrm{DBH}$, at seven year of age. In a K. ivorensis pure stand, at seven years of age, the $\mathrm{Ht}$ and $\mathrm{Hc}$ averages were 17.1 and $7.7 \mathrm{~m}$, respectively and DBH was $25.1 \mathrm{~cm}$, in Piumhi, MG, Brazil (Oliveira et al., 2018). 
A reduction of the initial density of 250 trees $^{-1}$ was observed in all plots, which corresponds to $33 \%$ mortality rate. Silva \& Schwartz (2019) evaluated the survival of forest species in the CLFI system in the municipality of Paragominas, in the state of Pará, Brazil, and found $73.1 \%$ survival rate for $K$. ivorensis. Because of $K$. grandifoliola vulnerability in the integrated production system, special attention should be given to the species responses in the establishment, as the initial mortality at planting will be increased by the mortality caused by cattle predation.

The high variability observed for the commercial height in the plots, with $29 \% \mathrm{CV}$, reflects the characteristic of heterogeneity for the height of the tree canopy insertion. However, for branching below $3.5 \mathrm{~m}$ in only $9.6 \%$ of the sampled trees, the species is characterized as suitable for the formation of branchfree stem.

The damage incidence was observed on the wood and bark, as the branches and the leaves of the trees were no longer within animal reaching when they were introduced. Superficial wounds were the most frequent $(51 \%)$ in the system, followed by lesion with impaired wood (46\%) characterized by surpassing the cambium, phloem, and xylem (Figure 1). Deep lesions at the base of the trunk impaired the supply of quality timber, since the base produces larger pieces of greater added-value. Damage was observed in all evaluated $K$.

Table 1. Dendrometric parameters of African mahogany (Khaya grandifoliola) in a silvipastural system, in the southwestern of Mato Grosso state, Brazil, in 2016.

\begin{tabular}{lccccc}
\hline Plot & $\begin{array}{c}\mathrm{DBH} \pm \mathrm{SD} \\
(\mathrm{cm})\end{array}$ & $\begin{array}{c}\mathrm{Ht} \pm \mathrm{SD} \\
(\mathrm{m})\end{array}$ & $\begin{array}{c}\mathrm{Hc} \pm \mathrm{SD} \\
(\mathrm{m})\end{array}$ & $\begin{array}{c}\text { Mortality } \\
(\%)\end{array}$ & $\begin{array}{c}\text { Density } \\
\left(\text { tree ha }^{-1}\right)\end{array}$ \\
\hline 1 & $18.5 \pm 3.0$ & $17.4 \pm 2.7$ & $11.0 \pm 2.7$ & 32.0 & 170 \\
2 & $17.8 \pm 3.3$ & $14.7 \pm 2.3$ & $8.3 \pm 2.3$ & 4.0 & 240 \\
3 & $20.3 \pm 3.6$ & $13.5 \pm 2.0$ & $4.9 \pm 3.2$ & 48.0 & 130 \\
4 & $16.3 \pm 2.5$ & $13.1 \pm 1.6$ & $7.8 \pm 1.5$ & 36.0 & 160 \\
5 & $16.5 \pm 3.1$ & $11.6 \pm 2.1$ & $6.6 \pm 1.9$ & 12.0 & 220 \\
6 & $15.3 \pm 3.7$ & $11.5 \pm 3.0$ & $6.0 \pm 2.0$ & 44.0 & 140 \\
7 & $14.1 \pm 2.2$ & $9.6 \pm 1.5$ & $5.4 \pm 1.2$ & 32.0 & 170 \\
8 & $14.2 \pm 2.5$ & $10.5 \pm 1.9$ & $5.6 \pm 2.4$ & 52.0 & 120 \\
\hline OM & 16.6 & 12.7 & 6.9 & 32.5 & 169 \\
\hline CV $(\%)$ & 12.91 & 19.55 & 29.00 & 51.98 & 25.03 \\
\hline
\end{tabular}

$\mathrm{DBH}$, diameter at breast height of $1.30 \mathrm{~m}$; Ht, total height; Hc, commercial height; SD, standard deviation; density, number of trees per hectare; OM, overall mean; CV (\%), coefficient of variation in percentage. grandifoliola trees, at different intensities. Depth and length of bark and wood lesions showed that damage intensity was low in $32 \%$ of the trees, medium in $46 \%$, and high in $22 \%$.

Trunk breakage at the height of the largest lesion was observed in 3\% of the trees (Figure 1), preventing the trees recovery, which impaired the supply of the trees with a straight trunk, or adequate wood quality, at the end of the commercial rotation. Broken trees, whether regenerated, can suffer loss of the apical dominance and show buds at low heights, compromising the wood splitter and the use of logs in sawmill.

The factors that make animals search for food in trees rather than in forage plants are the quantity and quality of forage, stress or previous learning, and chemical compounds in bark on trees (Brun et al., 2017), besides the differences in the thickness, texture, and softness of barks, or the presence of chemical compounds with nutritional appeal, such as starch, or the presence of compounds that inhibit bark chewing, such as essential oils and condensed tannins (Porfírioda-Silva et al., 2012). In the same environment, in paddocks with $T$. grandis, no damage was observed in the trees, which indicates the preferences of the animals for $K$. grandifoliola barks. Animals with this habit commonly show preferences for certain species of trees (Nicodemo \& Porfírio-da-Silva, 2019). This preference may be associated with the intrinsic characteristics of the species of the present study. Aversion to T. grandis bark may be related to the presence of anthraquinones, such as tectoquinone, which gives it a natural resistance to xylophagous organisms, but may also cause general intoxication in mammals (Leonardo et al., 2015). Besides, K. grandifoliola bark has medicinal properties and is traditionally used in the treatment of various types of diseases, including infectious ones (Tepongning et al., 2011). Therefore, further studies on the nutritional characteristics of the bark of the trees should be carried out to verify which factor could be attractive to animals to consume tree barks.

In a silvipastural system, $K$. grandifoliola displays an adequate growth and development of branch-free stem. However, the bark chewing by cattle results in the incidence of damage in $100 \%$ trees, with almost $70 \%$ impairment of the wood. The damages were of medium and high intensities. Therefore, $K$. grandifoliola may be considered a vulnerable species in production systems integrated with grazing cattle. 


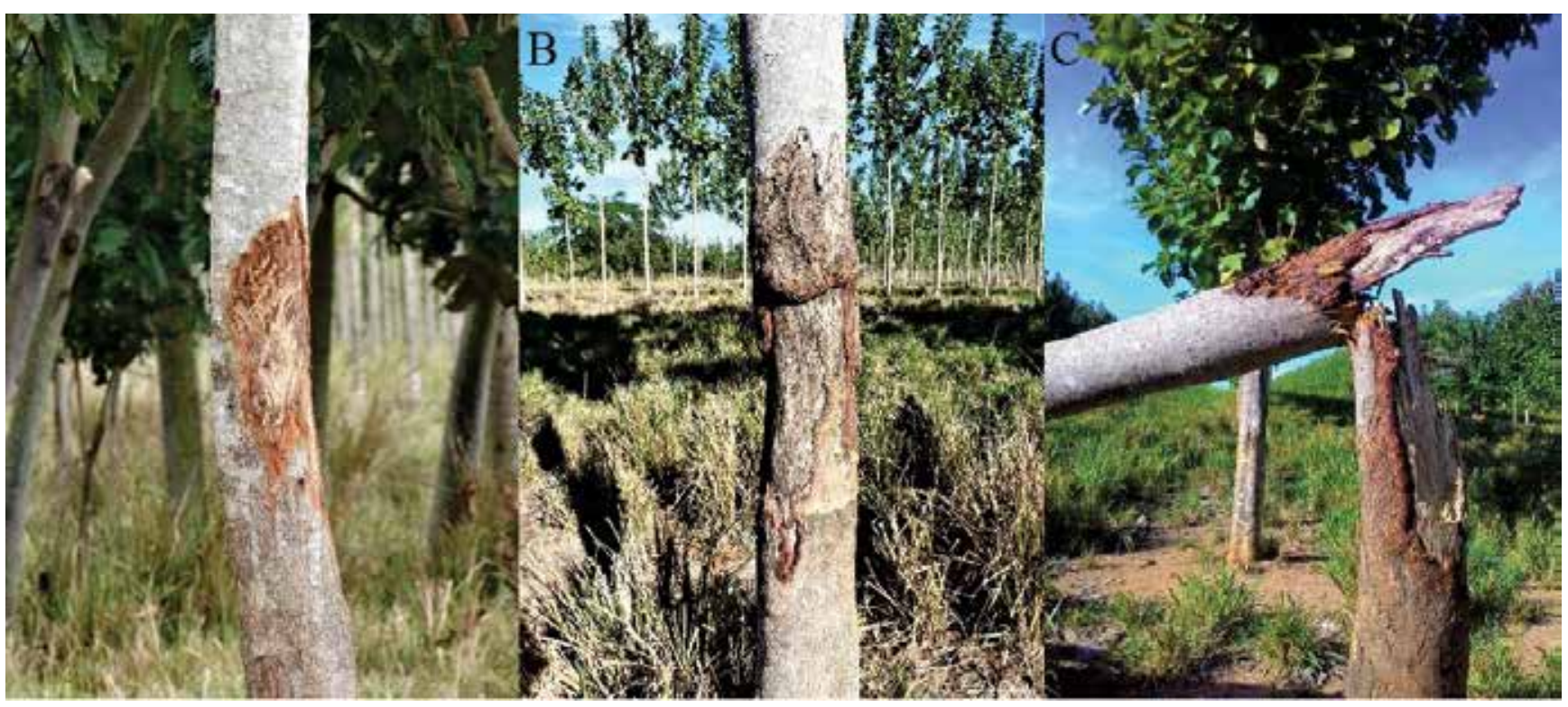

Figure 1. Classes of animal damage in Khaya ivorensis trees in silvipastoril system, in the southwestern of Mato Grosso state, Brazil, in 2016: A, superficial injury; B, deep injury; and C, main trunk break with Tectona grandis without injury to the bottom. Photos by Danielly Daiane Felix da Silva.

\section{References}

BALBINO, L.C.; CORDEIRO, L.A.M.; PORFÍRIO-DA-SILVA, V.; MORAES, A. de; MARTÍNEZ, G.B.; ALVARENGA, R.C.; KICHEL, A.N.; FONTANELI, R.S.; SANTOS, H.P. dos; FRANCHINI, J.C.; GALERANI, P.R. Evolução tecnológica e arranjos produtivos de sistemas de integração lavoura-pecuáriafloresta no Brasil. Pesquisa Agropecuária Brasileira, v.46, p.i-xii, 2011. DOI: https://doi.org/10.1590/S0100-204X2011001000001.

BRUN, E.J.; DALPOSSO, D.M.; KUSS, F.; SARTOR, L.R.; BRUN, F.G.K.; PERETIATKO, C.D.S. Danos causados por gado leiteiro no componente arbóreo de um sistema silvipastoril. Ecologia e Nutrição Florestal, v.5, p.33-44, 2017. DOI: https://doi.org/10.5902/2316980X25634.

CASTRO, A.C.; LOURENÇO JÚNIOR, J. de B.; SANTOS, N. de F.A. dos; MONTEIRO, E.M.M.; AVIZ, M.A.B. de; GARCIA, A.R. Sistema silvipastoril na Amazônia: ferramenta para elevar o desempenho produtivo de búfalos. Ciência Rural, v.38, p.2395-2402, 2008. DOI: https://doi.org/10.1590/S010384782008000800050 .

FIKE, J.H.; BUERGLER, A.L.; BURGER, J.A.; KALLENBACH, R.L. Considerations for establishing and managing silvopastures. Forage and Grazinglands, 2004. DOI: https://doi.org/10.1094/ FG-2004-1209-01-RV.

KICHEL, A.N.; COSTA, J.A.A. da; ALMEIDA, R.G. de; PAULINO, V.T. Sistemas de integração lavoura-pecuária-floresta (iLPF) - experiências no Brasil. Boletim de Indústria Animal, v.71, p.94-105, 2014.

KLEIN, D.R.; ANDRADE, M.M.; DERENGOSKI, J.A.; DUARTE, E.; KREFTA, S.M.; SILVEIRA, A.C. da; BRUN,
E.J. Aspectos gerais e silviculturais de Cordia americana, Aspidosperma polyneuron, Toona ciliata e Khaya spp. Revista de Ciências Agroveterinárias, v.15, p.155-164, 2016. DOI: https://doi.org/10.5965/223811711522016155.

LEHMKUHLER, J.W.; FELTON, E.E.D.; SCHMIDT, D.A.; BADER, K.J.; GARRET, H.E.; KERLEY, M.S. Tree protection methods during the silvopastoral-system establishment in midwestern USA: cattle performance and tree damage. Agroforestry Systems, v.59, p.35-42, 2003. DOI: https://oi.org/10.1023/A:1026184902984.

LEONARDO, F.V. da S.; ROCHA, H.F.; MENDOZA, Z.M. dos S.H. de. Compostos químicos em teca. Pesquisa Florestal Brasileira, v.35, p.315-322, 2015. DOI: https://doi. org/10.4336/2015.pfb.35.83.816.

NICODEMO, M.L.F.; PORFÍRIO-DA-SILVA, V. Bark stripping by cattle in silvopastoral systems. Agroforestry Systems, v.93, p.305-315, 2019. DOI: https://doi.org/10.1007/ s10457-018-0185-y.

OLIVEIRA, X.M. de; RIBEIRO, A.; FERRAZ FILHO, A.C.; MAYRINCK, R.C.; LIMA, R.R. de; SCOLFORO, J.R.S. Volume equations for Khaya ivorensis A. Chev. plantations in Brazil. Anais da Academia Brasileira de Ciências, v.90, p.3285-3298, 2018. DOI: https://doi.org/10.1590/0001-3765201820170852.

PORFÍRIO-DA-SILVA, V.; MORAES, A. de; MOLETTA, J.L.; PONTES, L. da S.; OLIVEIRA, E.B. de; PELISSARI, A.; CARVALHO, P.C. de F. Danos causados por bovinos em diferentes espécies arbóreas recomendadas para sistemas silvipastoris. Pesquisa Florestal Brasileira, v.32, p.183-192, 2012. DOI: https://doi.org/10.4336/2012.pfb.32.70.67. 
SILVA, A.R.; SCHWARTZ, G. Sobrevivência e crescimento inicial de espécies florestais em sistema de integração lavoura-pecuária-floresta no leste da Amazônia. Revista em Agronegócio e Meio Ambiente, v.12, p.45-63, 2019. DOI: https://doi.org/10.17765/2176-9168.2019v12n1p45-63.
TEPONGNING, R.N.; LUCANTONI, L.; NASUTI, C.C.; DORI, G.U.; YERBANGA, S.R.; LUPIDI, G.; MARINI, C.; ROSSI, G.; ESPOSITO, F.; HABLUETZEL, A. Potential of a Khaya ivorensis-Alstonia boonei extract combination as antimalarial prophylactic remedy. Journal of Ethnopharmacology, v.137, p.743-751, 2011. DOI: https://doi.org/10.1016/j.jep.2011.06.036. 